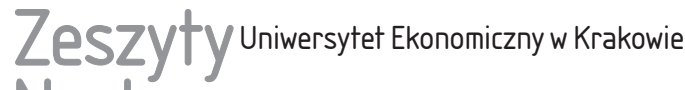 Naukowe
}

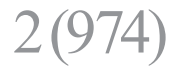

ISSN 1898-6447

Zesz. Nauk. UEK, 2018; 2 (974): 167-183

https://doi.org/10.15678/ZNUEK.2018.0974.0210

Krystyna Ciuman

\section{Ulgi a preferencje podatkowe w podatkach dochodowych w Polsce}

\section{Streszczenie}

W artykule przedstawiono ulgi podatkowe i preferencje podatkowe w podatkach dochodowych (PIT oraz CIT) w Polsce w latach 2010-2015. Przez ulgi podatkowe rozumiano możliwości zmniejszania dochodu lub obliczonego podatku o określone wielkości (głównie na podstawie ustawy o danym podatku). Ulgi od dochodu zmniejszały podstawę opodatkowania, a więc wpływały pośrednio na wysokość podatku. Ulgi od podatku powodowały obniżenie podatku o kwotę ulgi. Przez preferencje podatkowe rozumiano natomiast odstępstwa od przyjętego w danym kraju standardu podatkowego.

Zarówno ulgi podatkowe, jak i preferencje podatkowe są ważnymi instrumentami polityki fiskalnej sprzyjającymi realizowaniu funkcji regulacyjnej oraz stymulacyjnej podatków. Powodują one jednak zmniejszenie dochodów budżetowych z tytułu podatków, chociaż czynią to $\mathrm{w}$ różnym stopniu. W artykule scharakteryzowano wielkość, strukturę i tendencje kształtowania się ulg oraz preferencji podatkowych, a także podjęto próbę ich oceny. Ukazano też, w jakim stopniu wpłynęły one na zmniejszenie się dochodów budżetowych z tytułu podatku dochodowego od osób fizycznych i podatku dochodowego od osób prawnych.

Słowa kluczowe: ulgi podatkowe, preferencje podatkowe, dochody budżetowe, podatki dochodowe.

Klasyfikacja JEL: H24.

Krystyna Ciuman, Uniwersytet Ekonomiczny w Krakowie, Wydział Finansów i Prawa, Katedra Finansów, ul. Rakowicka 27, 31-510 Kraków, e-mail: ciumank@uek.krakow.pl 


\section{Wprowadzenie}

Problematyka kształtowania się wysokości podatków, a także społecznych i gospodarczych celów podatków jest nadal aktualna i szeroko omawiana, dlatego warto przyjrzeć się bliżej zagadnieniu ulg i preferencji podatkowych. Instrumenty te umożliwiają bowiem kształtowanie wielkości dochodów podatkowych budżetu państwa oraz budżetów jednostek samorządu terytorialnego w sposób sprzyjający realizowaniu regulacyjnej oraz stymulacyjnej funkcji podatków.

Niniejszy artykuł ma charakter empiryczny. Jego celem jest omówienie, a także próba oceny ulg i preferencji podatkowych w obowiązujących w Polsce podatku dochodowym od osób fizycznych (PIT) oraz podatku dochodowym od osób prawnych (CIT). Przede wszystkim chodzi o zaprezentowanie ich wielkości, struktury, tendencji kształtowania się oraz wpływu na zmniejszanie się dochodów budżetowych. Odniesiono również wielkość ulg i preferencji podatkowych do wielkości deficytu sektora finansów publicznych.

Okres badawczy obejmuje lata 2010-2015 w zakresie ulg podatkowych, a w odniesieniu do preferencji podatkowych lata 2010-2014, co związane było z dostępem do szczegółowych materiałów źródłowych. Wykorzystano dane liczbowe publikowane przez GUS, jak również udostępniane przez Ministerstwo Finansów raporty Informacje dotyczqce rozliczenia podatku dochodowego od osób fizycznych za lata 2010-2015, raporty Informacje dotyczqce rozliczenia podatku dochodowego od osób prawnych za lata 2010-2015 oraz raporty Preferencje podatkowe $w$ Polsce za lata 2010-2014.

W artykule omówiono zagadnienia takie jak: istota ulg i preferencji podatkowych, ulgi podatkowe w podatkach dochodowych, preferencje podatkowe w podatkach dochodowych, ocena wielkości oraz finansowych skutków ulg i preferencji podatkowych.

\section{Istota ulg i preferencji podatkowych}

W gospodarce rynkowej podatki pełnią funkcję fiskalną, regulacyjną i stymulacyjną (Wolański 2009). Funkcję fiskalną pełnią wszystkie podatki, gdyż wszystkie są źródłem dochodów budżetowych. Jak słusznie podkreślił P.M. Gaudemet, podatki zostały wymyślone i wprowadzone po to, aby dostarczać państwu dochodów. Brak dochodów z tytułu podatków oznaczałby jednocześnie brak możliwości finansowania wydatków publicznych. Istnieje wprawdzie ewentualność zaciągania pożyczek, jednakże pożyczki nie mogą zastąpić (wyeliminować) podatków. Dzieje się tak dlatego, że pożyczki są zwrotne, co pociąga za sobą konieczność ich obsługi. Ponadto pożyczki wraz z oprocentowaniem spłacane 
są z pobrań podatkowych (Gaudemet 1989). Wobec powyższego pożyczki mogą stanowić jedynie uzupełniające źródło finansowania wydatków publicznych.

Obok funkcji fiskalnej podatki mogą też pełnić funkcje pozafiskalne, do których zaliczane są funkcje regulacyjna i stymulacyjna. Wymienione funkcje są ważne ze względów społecznych i gospodarczych. Umożliwiają bowiem kształtowanie dochodów i majątku podatników (funkcja regulacyjna), a także mogą wpływać na decyzje gospodarcze podatników oraz na osiąganie pożądanych efektów społecznych (funkcja stymulacyjna) (Wolański 2009).

Zgodnie z poglądem S. Owsiaka (2017, s. 228 i 229) „władze publiczne muszą posługiwać się podatkami w sposób racjonalny, tzn. umiejętnie łączyć interesy fiskalne państwa z interesami ekonomicznymi podatników, realizację celów społecznych z ochroną gospodarki przed negatywnymi skutkami podatkowymi". Dla osiągnięcia tego celu warto posłużyć się ulgami i preferencjami podatkowymi, które są instrumentami mogącymi poprawić sytuację podatników, a także skłonić ich do określonych działań.

W Ordynacji podatkowej (Ustawa z dnia 29 sierpnia 1997 r....) ulgi podatkowe definiowane są szeroko i obejmują przewidziane w przepisach prawa podatkowego zwolnienia, odliczenia, obniżki albo zmniejszenia, których zastosowanie powoduje obniżenie podstawy opodatkowania lub wysokości podatku. Korzystanie z ulg podatkowych ma zapewnić podatnikom zmniejszenie ciężaru podatkowego, co jest szczególnie widoczne w przypadku podatków dochodowych.

Ulgi podatkowe mogą przybierać formę odliczeń od dochodu (i przyczyniać się do zmniejszenia podstawy opodatkowania) oraz odliczeń od podatku, ale wielu ekonomistów uważa, że lepszym rozwiązaniem jest stosowanie tych drugich. Swoją opinię uzasadniają tym, że odliczenia od dochodu przynoszą najwięcej korzyści osobom z najwyższych przedziałów podatkowych. W niektórych sytuacjach zasada sprawiedliwości może jednak przesądzać o stosowaniu odliczeń od dochodu (Stiglitz 2004). Należy dodać, że finansowe skutki ulg podatkowych nie są znane ex ante.

Zaprezentowane w niniejszym opracowaniu ulgi podatkowe obejmują odliczenia publikowane przez GUS, jednak z tą różnicą, że przy odliczeniach od dochodu w PIT nie brano pod uwagę składek na ubezpieczenia społeczne, a przy odliczeniach od podatku w PIT pominięto składki na ubezpieczenia zdrowotne. Badano zatem te odliczenia, których zastosowanie miało wpływ na zmniejszenie dochodów sektora publicznego.

Należy podkreślić, że każde wykorzystanie przez podatników ulgi podatkowej pozbawia budżet państwa lub budżet jednostki samorządu terytorialnego części dochodów podatkowych. Dla podatników skutkiem stosowania ulg podatkowych jest natomiast zmniejszenie zobowiązań podatkowych, chociaż istnieją pewne wyjątki. Przykładowo przekazanie $1 \%$ podatku (PIT) na rzecz organizacji pożytku 
publicznego nie zmniejsza zobowiązania podatkowego podatnika, lecz pozwala mu decydować o przeznaczeniu określonej ilości pochodzących od niego środków pieniężnych.

Preferencje podatkowe zgodnie z definicją proponowaną przez OECD oznaczają wszelkie odstępstwa od przyjętego w danym kraju standardu podatkowego (Preferencje podatkowe... 2010). Można więc stwierdzić, że preferencje stwarzają możliwości opodatkowania na warunkach korzystniejszych dla podatników od powszechnie stosowanych. Wykorzystywanie preferencji zawsze skutkuje zmniejszeniem obciążenia podatkowego przy równoczesnym zmniejszeniu dochodów budżetowych z tytułu podatków. Ponadto preferencje kierowane są do nieokreślonej liczby podatników. Środki pieniężne zaoszczędzone przez podatników dzięki istnieniu omawianych preferencji mają ich skłonić do oczekiwanych przez państwo zachowań.

Preferencje podatkowe są wprawdzie pojęciem szerszym niż ulgi podatkowe, ale nie oznacza to, że wszystkie ulgi podatkowe są jednocześnie preferencjami podatkowymi. Preferencje mogą występować w różnych formach, ale najczęściej są to zwolnienia, odliczenia, obniżone stawki, zaniechania. Wartość preferencji jest szacowana, gdyż nie zawsze jest możliwe dokładne ich poznanie. W Polsce były one szacowane metodą utraconych wpływów (Preferencje podatkowe... 2010). Skutki finansowe preferencji podobnie jak skutki ulg podatkowych nie są znane ex ante. Stosowanie preferencji podatkowych wywiera wpływ na transparentność polityki fiskalnej. Właściwa ocena funkcjonowania preferencji podatkowych uwarunkowana jest ich uprzednim zidentyfikowaniem, możliwie dobrym oszacowaniem i jawnością (Dziemianowicz, Wyszkowski i Budlewska 2014).

$\mathrm{Z}$ jednej strony bezpośrednim skutkiem wykorzystania ulg i preferencji podatkowych jest uszczuplenie dochodów podatkowych, ale z drugiej strony ułatwiają one sprawiedliwe rozłożenie ciężarów podatkowych, co może zmniejszać pokusę ucieczki przed podatkiem.

\section{Ulgi podatkowe w podatkach dochodowych w Polsce w latach 2010-2015}

W podatku dochodowym od osób fizycznych przewidziane są ustawowo ulgi od dochodu oraz ulgi od podatku. Różny jest skutek budżetowy wymienionych ulg. Ulgi od dochodu obniżają uzyskane dochody o kwotę ulgi, co prowadzi do zmniejszenia podstawy opodatkowania, a w konsekwencji do zmniejszenia podatku. Kwota obniżenia podatku zależy bowiem od kwoty ulgi oraz stawki podatku. Ulgi od podatku powodują natomiast zmniejszenie podatku o kwotę ulgi, a zatem wpływają bezpośrednio na wielkość podatku należnego. 
Wielkość i strukturę ulg podatkowych od dochodu w PIT zaprezentowano w tabeli 1. Ulgi te kształtowały sie różnie, lecz od 2013 r. nastąpił ich znaczny spadek, co było spowodowane głównie ograniczeniem ulgi na Internet. Wśród ulg od dochodu dominowała (oprócz 2012 r.) ulga dotycząca wydatków na cele rehabilitacyjne. Jej udział w rozpatrywanych ulgach w latach 2010-2012 wynosił średnio 44,5\%, a w kolejnych latach (po ograniczeniu ulgi na Internet) był równy średnio 70,6\%. Ulga na Internet w latach 2010-2012 stanowiła średnio 42,5\% ulg od dochodu, a w kolejnych trzech latach $7,1 \%$ tych ulg. Jedynie ulga z tytułu darowizn wykazywała w całym badanym okresie tendencję rosnącą, lecz jej znaczenie finansowe było o wiele mniejsze niż ulgi na cele rehabilitacyjne (ulga z tytułu darowizn przybierała wartości od 3,6\% do 10,3\% ulg od dochodu). Inne ulgi, np. z tytułu wpłat na IKZE lub odliczeń na zasadzie praw nabytych, zawarto w pozycji ,pozostałe ulgi”. W badanym przedziale czasu wynosiły one od $7,7 \%$ do $14,7 \%$ ulg od dochodu.

Tabela 1. Wielkość i struktura ulg podatkowych od dochodu w PIT w latach 2010-2015

\begin{tabular}{|l|c|c|c|c|c|c|}
\hline \multicolumn{1}{|c|}{ Wyszczególnienie } & 2010 & 2011 & 2012 & 2013 & 2014 & 2015 \\
\hline Ulgi podatkowe od dochodu (w mln zł): & 5458 & 5583 & 5388 & 3160 & 3476 & 3596 \\
\hline - darowizny & 198 & 276 & 326 & 327 & 337 & 365 \\
\hline - wydatki na cele rehabilitacyjne & 2551 & 2497 & 2272 & 2214 & 2491 & 2517 \\
\hline $\begin{array}{l}\text { - wydatki z tytułu użytkowania sieci } \\
\text { Internet }\end{array}$ & 2278 & 2384 & 2340 & 305 & 221 & 184 \\
\hline - pozostałe ulgi & 431 & 426 & 450 & 314 & 427 & 530 \\
\hline Ulgi podatkowe od dochodu (w \%): & 100,0 & 100,0 & 100,0 & 100,0 & 100,0 & 100,0 \\
\hline - darowizny & 3,6 & 4,9 & 6,1 & 10,3 & 9,7 & 10,2 \\
\hline - wydatki na cele rehabilitacyjne & 46,7 & 44,7 & 42,2 & 70,1 & 71,7 & 70,0 \\
\hline - wydatki z tytułu użytkowania sieci & 41,7 & 42,7 & 43,2 & 9,7 & 6,4 & 5,1 \\
\hline Internet & & & & & & \\
\hline - pozostałe ulgi & 8,0 & 7,7 & 8,5 & 9,9 & 12,2 & 14,7 \\
\hline
\end{tabular}

Źródło: obliczenia własne na podstawie (Informacje dotyczqce rozliczenia podatku dochodowego od osób fizycznych... 2011-2016).

W celu lepszego ukazania rozmiaru ulg podatkowych od dochodu w PIT można je odnieść do uzyskanego przez osoby fizyczne dochodu (będącego przedmiotem podatku). Z rys. 1 wynika, że w latach 2010-2012 relacja ulg podatkowych od dochodu do dochodu wynosiła średnio $0,84 \%$, a w kolejnych trzech latach $0,47 \%$. Ciągły wzrost dochodów oraz zmniejszenie od 2013 r. ulg podatkowych od dochodu wpłynęły na rozmiary omawianej relacji. 


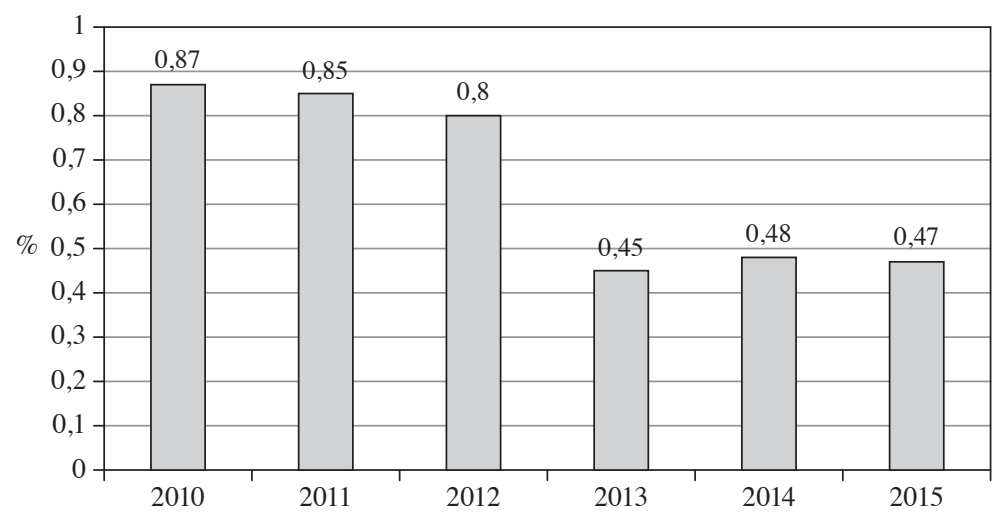

Rys. 1. Relacja ulg podatkowych od dochodu w PIT do dochodu w latach 2010-2015 (w \%)

Źródło: obliczenia własne na podstawie (Informacje dotyczqce rozliczenia podatku dochodowego od osób fizycznych... 2011-2016).

Wielkość i strukturę ulg od podatku w PIT w latach 2010-2015 zamieszczono w tabeli 2. Wielkość tych ulg kształtowała się różnie i w 2015 r. były one niższe niż w 2010 r. o $0,1 \%$. W całym rozpatrywanym okresie zdecydowanie dominowała ulga na dzieci, której udział w strukturze ulg wahał się od 96,1\% do 98,2\%.

Tabela 2. Wielkość i struktura ulg od podatku w PIT w latach 2010-2015

\begin{tabular}{|l|c|c|c|c|c|c|}
\hline \multicolumn{1}{|c|}{ Wyszczególnienie } & 2010 & 2011 & 2012 & 2013 & 2014 & 2015 \\
\hline Ulgi od podatku (w mln zł): & 5848 & 5864 & 5835 & 5631 & 5763 & 5844 \\
\hline - na dzieci & 5684 & 5740 & 5699 & 5530 & 5589 & 5617 \\
\hline - pozostałe ulgi & 164 & 124 & 136 & 101 & 174 & 227 \\
\hline Ulgi od podatku (w \%): & 100,0 & 100,0 & 100,0 & 100,0 & 100,0 & 100,0 \\
\hline - na dzieci & 97,2 & 97,9 & 97,7 & 98,2 & 97,0 & 96,1 \\
\hline - pozostałe ulgi & 2,8 & 2,1 & 2,3 & 1,8 & 3,0 & 3,9 \\
\hline
\end{tabular}

Źródło: obliczenia własne na podstawie (Informacje dotyczqce rozliczenia podatku dochodowego od osób fizycznych... 2011-2016).

Wskazane wydaje się zestawienie wielkości oraz skutku budżetowego ulg od dochodu z ulgami od podatku (tabela 3 ). W badanym przedziale czasu ulgi od podatku zawsze przewyższały ulgi od dochodu, przy czym w latach 2010-2012 ulgi od dochodu stanowiły średnio 48,4\% ulg razem, a w kolejnym podokresie $37,2 \%$. Skutek budżetowy ulg od podatku (równy ulgom od podatku) był zdecy- 
dowanie wyższy niż skutek budżetowy (w latach 2013-2015 oszacowany skutek budżetowy) ulg od dochodu. Tytułem wyjaśnienia należy dodać, że skutek budżetowy ulg od dochodu został wyliczony dla lat 2010-2012. Były wówczas publikowane dane dotyczące odliczeń od dochodu także w rozbiciu na dwa progi podatkowe. W kolejnych latach podawane były odliczenia od dochodu ogółem. W badanym okresie obowiązywały niezmiennie dwie stawki podatku (18\% i 32\%), lecz gros osób fizycznych płaciło podatek według stawki $18 \%$. Wobec powyższego przyjęto, że oszacowany skutek budżetowy ulg podatkowych od dochodu będzie równy $19 \%$ wartości tych ulg. Przedstawiony szacunek jest wprawdzie ogólny, ale umożliwia przybliżenie wielkości skutku budżetowego ulg. W latach 2010-2012 skutek budżetowy ulg od dochodu wynosił średnio 15,2\%, a w kolejnych trzech latach $10,1 \%$ ulg razem. Skutek budżetowy ulg od podatku w obu podokresach stanowił odpowiednio $84,8 \%$ oraz $89,9 \%$ ulg razem.

Tabela 3. Wielkość i skutek budżetowy ulg podatkowych w PIT w latach 2010-2015

\begin{tabular}{|l|c|c|c|c|c|c|c|}
\hline \multicolumn{1}{|c|}{ Wyszczególnienie } & 2010 & 2011 & 2012 & 2013 & 2014 & 2015 \\
\hline Ulgi (w mln zł): & 5458 & 5583 & 5388 & 3160 & 3476 & 3596 \\
\hline - od dochodu & 5848 & 5864 & 5835 & 5631 & 5763 & 5844 \\
\hline - od podatku & 11306 & 11447 & 11223 & 8791 & 9239 & 9440 \\
\hline - razem & 1028 & 1069 & 1035 & 600 & 660 & 683 \\
\hline Skutek budżetowy (w mln zł): & 5848 & 5864 & 5835 & 5631 & 5763 & 5844 \\
\hline - ulg od dochodu a & 6876 & 6933 & 6870 & 6231 & 6423 & 6527 \\
\hline - ulg od podatku & 48,3 & 48,8 & 48,0 & 35,9 & 37,6 & 38,1 \\
\hline - ulg razem & 51,7 & 51,2 & 52,0 & 64,1 & 62,4 & 61,9 \\
\hline Ulgi (w \%): & 100,0 & 100,0 & 100,0 & 100,0 & 100,0 & 100,0 \\
\hline - od dochodu & 15,0 & 15,4 & 15,1 & 9,6 & 10,3 & 10,5 \\
\hline - od podatku & 85,0 & 84,6 & 84,9 & 90,4 & 89,7 & 89,5 \\
\hline - razem & 100,0 & 100,0 & 100,0 & 100,0 & 100,0 & 100,0 \\
\hline Skutek budżetowy (w \%):
\end{tabular}

${ }^{a}$ w latach 2013-2015 podano wielkości szacunkowe.

Źródło: obliczenia własne na podstawie (Informacje dotyczqce rozliczenia podatku dochodowego od osób fizycznych... 2011-2016).

W podatku dochodowym od osób prawnych przewidziane są ulgi podatkowe od dochodu, odliczenia od podstawy opodatkowania oraz ulgi od podatku. Wielkość i strukturę ulg od dochodu i podstawy opodatkowania w CIT w latach 
Tabela 4. Wielkość i struktura ulg podatkowych od dochodu i podstawy opodatkowania w CIT w latach 2010-2015

\begin{tabular}{|l|c|c|c|c|c|c|}
\hline \multicolumn{1}{|c|}{ Wyszczególnienie } & 2010 & 2011 & 2012 & 2013 & 2014 & 2015 \\
\hline Straty z lat ubiegłych (w mln zł) & 11280 & 14487 & 13557 & 15929 & 15609 & 13705 \\
\hline $\begin{array}{l}\text { Ulgi od dochodu (bez strat z lat ubiegłych) } \\
\text { (w mln zł) }\end{array}$ & 333 & 284 & 344 & 324 & 392 & 322 \\
\hline $\begin{array}{l}\text { Odliczenia od podstawy opodatkowania } \\
\text { wydatków na nabycie nowych technologii } \\
\text { (w mln zł) }\end{array}$ & 31 & 271 & 439 & 307 & 284 & 390 \\
\hline Razem & 11644 & 15042 & 14340 & 16560 & 16285 & 14417 \\
\hline Straty z lat ubiegłych (w \%) & 96,9 & 96,3 & 94,5 & 96,2 & 95,8 & 95,1 \\
\hline $\begin{array}{l}\text { Ulgi od dochodu (bez strat z lat ubiegłych) } \\
\text { (w \%) }\end{array}$ & 2,8 & 1,9 & 2,4 & 1,9 & 2,5 & 2,2 \\
\hline $\begin{array}{l}\text { Odliczenia od podstawy opodatkowania } \\
\text { wydatków na nabycie nowych technologii } \\
\text { (w \%) }\end{array}$ & 0,3 & 1,8 & 3,1 & 1,9 & 1,7 & 2,7 \\
\hline Razem & 100,0 & 100,0 & 100,0 & 100,0 & 100,0 & 100,0 \\
\hline
\end{tabular}

Źródło: obliczenia własne na podstawie (Informacje dotyczqce rozliczenia podatku dochodowego od osób prawnych... 2011-2016).

2010-2015 przedstawiono w tabeli 4. Charakterystyczne jest to, że wszystkie zamieszczone w tabeli wielkości kształtowały sie różnie, jednakże w strukturze ulg zdecydowanie dominowały straty z lat ubiegłych, które wynosiły średnio 95,8\% ulg ogółem. Ulgi od dochodu (bez strat z lat ubiegłych) stanowiły średnio $2,3 \%$ ulg, a odliczenia od podstawy opodatkowania wydatków na nabycie nowych technologii $1,9 \%$. Jeśli chodzi o strukturę samych ulg od dochodu (bez strat z lat ubiegłych), to w badanym przedziale czasu największe znaczenie finansowe miała ulga dotycząca darowizn. Jej udział w ulgach od dochodu wynosił od 76,8\% do 98,2\% (tabela 5).

Tabela 5. Struktura ulg podatkowych od dochodu w CIT w latach 2010-2015

\begin{tabular}{|l|c|c|c|c|c|c|}
\hline \multicolumn{1}{|c|}{ Wyszczególnienie } & 2010 & 2011 & 2012 & 2013 & 2014 & 2015 \\
\hline Ulgi podatkowe od dochodu (mln zł): & 333 & 284 & 344 & 324 & 392 & 322 \\
\hline - darowizny & 310 & 279 & 320 & 284 & 301 & 300 \\
\hline - pozostałe & 23 & 5 & 24 & 40 & 91 & 22 \\
\hline Ulgi podatkowe od dochodu (w \%): & 100,0 & 100,0 & 100,0 & 100,0 & 100,0 & 100,0 \\
\hline - darowizny & 93,1 & 98,2 & 93,0 & 87,7 & 76,8 & 93,2 \\
\hline - pozostałe & 6,9 & 1,8 & 7,0 & 12,3 & 23,2 & 6,8 \\
\hline
\end{tabular}

Źródło: obliczenia własne na podstawie (Informacje dotyczqce rozliczenia podatku dochodowego od osób prawnych... 2011-2016). 
Ciekawe jest odniesienie ulg podatkowych od dochodu i podstawy opodatkowania w CIT do uzyskanego przez osoby prawne dochodu (rys. 2). W badanym okresie relacja ulg od dochodu i podstawy opodatkowania do dochodu kształtowała sie w granicach od 5,6\% do 7,29\%, przy czym relacja strat z lat ubiegłych do dochodu wynosiła od $5,42 \%$ do $7,01 \%$, relacja ulg od dochodu (bez strat z lat ubiegłych) do dochodu od $0,12 \%$ do $0,16 \%$, a relacja odliczeń od podstawy opodatkowania do wydatków na nabycie nowych technologii od $0,02 \%$ do $0,2 \%$.

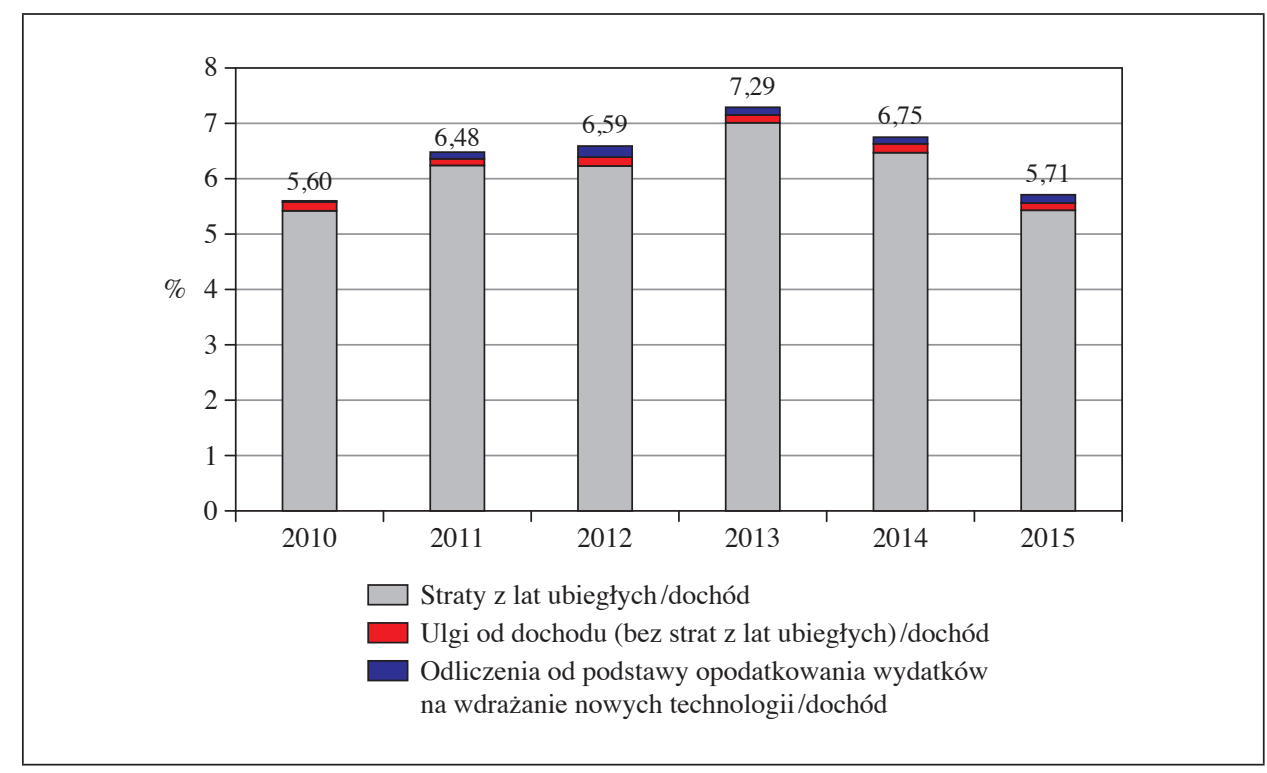

Rys. 2. Relacja ulg podatkowych od dochodu i podstawy opodatkowania w CIT do dochodu w latach 2010-2015 (w \%)

Źródło: obliczenia własne na podstawie (Informacje dotyczqce rozliczenia podatku dochodowego od osób prawnych... 2011-2016).

Informacje dotyczące odliczeń od podatku w CIT przedstawiono w tabeli 6 . W latach 2010-2013 odliczenia te ulegały stopniowemu obniżeniu, a w kolejnych latach nastąpił ich wzrost. W sprawozdaniach odnoszących się do ulg od podatku w CIT wyodrębnione zostały jedynie odliczenia dotyczące podatku zapłaconego za granicą. W latach 2010-2015 odliczenia $\mathrm{z}$ tego tytułu wynosiły od 39,5\% do $77,8 \%$ odliczeń ogółem. Ten zróżnicowany udział w strukturze odliczeń wynikał głównie ze zróżnicowania wielkości pozostałych odliczeń od CIT. 
Tabela 6. Wielkość i struktura odliczeń od podatku w CIT w latach 2010-2015

\begin{tabular}{|l|c|c|c|c|c|c|}
\hline \multicolumn{1}{|c|}{ Wyszczególnienie } & 2010 & 2011 & 2012 & 2013 & 2014 & 2015 \\
\hline Odliczenia od podatku (w mln zł): & 129 & 95 & 81 & 80 & 85 & 198 \\
\hline - podatek zapłacony za granicą & 51 & 56 & 59 & 50 & 66 & 84 \\
\hline - pozostałe & 78 & 39 & 22 & 30 & 19 & 114 \\
\hline Odliczenia od podatku (w \%): & 100,0 & 100,0 & 100,0 & 100,0 & 100,0 & 100,0 \\
\hline - podatek zapłacony za granicą & 39,5 & 58,9 & 72,8 & 62,5 & 77,6 & 42,4 \\
\hline - pozostałe & 60,5 & 41,1 & 27,2 & 37,5 & 22,4 & 57,6 \\
\hline
\end{tabular}

Źródło: obliczenia własne na podstawie (Informacje dotyczqce rozliczenia podatku dochodowego od osób prawnych... 2011-2016).

Tabela 7. Wielkość i skutek budżetowy ulg podatkowych w CIT w latach 2010-2015

\begin{tabular}{|c|c|c|c|c|c|c|}
\hline Wyszczególnienie & 2010 & 2011 & 2012 & 2013 & 2014 & 2015 \\
\hline \multicolumn{7}{|l|}{ Ulgi (w mln zł): } \\
\hline - od dochodu i podstawy opodatkowania & 11644 & 15042 & 14340 & 16560 & 16285 & 14417 \\
\hline - od podatku & 129 & 95 & 81 & 80 & 85 & 198 \\
\hline - razem & 11773 & 15137 & 14421 & 16640 & 16370 & 14615 \\
\hline \multicolumn{7}{|l|}{ Skutek budżetowy (w mln zł): } \\
\hline - ulg od dochodu i podstawy opodatkowania & 2212 & 2858 & 2725 & 3146 & 3094 & 2739 \\
\hline - ulg od podatku & 129 & 95 & 81 & 80 & 85 & 198 \\
\hline - ulg razem & 2341 & 2953 & 2806 & 3226 & 3179 & 2937 \\
\hline \multicolumn{7}{|l|}{ Ulgi (w \%): } \\
\hline - od dochodu i podstawy opodatkowania & 98,9 & 99,4 & 99,4 & 99,5 & 99,5 & 98,6 \\
\hline - od podatku & 1,1 & 0,6 & 0,6 & 0,5 & 0,5 & 1,4 \\
\hline - razem & 100,0 & 100,0 & 100,0 & 100,0 & 100,0 & 100,0 \\
\hline \multicolumn{7}{|l|}{ Skutek budżetowy (w \%): } \\
\hline - ulg od dochodu i podstawy opodatkowania & 94,5 & 96,8 & 97,1 & 97,5 & 97,3 & 93,3 \\
\hline - ulg od podatku & 5,5 & 3,2 & 2,9 & 2,5 & 2,7 & 6,7 \\
\hline - ulg razem & 100,0 & 100,0 & 100,0 & 100,0 & 100,0 & 100,0 \\
\hline $\begin{array}{l}\text { Skutek budżetowy ulg od dochodu i pod- } \\
\text { stawy opodatkowania (bez strat z lat ubie- } \\
\text { głych) (w mln zł) }\end{array}$ & 6,9 & 105 & 149 & 120 & 128 & 135 \\
\hline
\end{tabular}

Źródło: obliczenia własne na podstawie (Informacje dotyczqce rozliczenia podatku dochodowego od osób prawnych... 2011-2016).

Zestawienie wielkości oraz skutku budżetowego ulg od dochodu i podstawy opodatkowania z ulgami od podatku w CIT zawarto w tabeli 7. W badanych latach ulgi od dochodu i podstawy opodatkowania zdecydowanie przewyższały ulgi od 
podatku, stanowiły bowiem średnio $99,2 \%$ ulg razem. W konsekwencji skutek budżetowy tych ulg był dominujący i wynosił średnio 96,1\% skutku budżetowego ulg razem. Jeśli natomiast weźmiemy pod uwagę ulgi od dochodu i podstawy opodatkowania bez strat z lat ubiegłych, to ich skutek budżetowy był znacznie mniejszy, ale przewyższał skutek budżetowy ulg od podatku w latach 2011-2014.

\section{Preferencje podatkowe w podatkach dochodowych w Polsce w latach 2010-2014}

W całym badanym okresie rosła wartość preferencji podatkowych w podatkach dochodowych ogółem, przy czym w podatku dochodowym od osób fizycznych w jednym roku obniżyła się (w 2012 r. wartość preferencji uległa obniżeniu w stosunku do roku poprzedniego o 1,6\%), natomiast zawsze rosła w podatku dochodowym od osób prawnych. Wielkość i strukturę preferencji w podatkach dochodowych zaprezentowano w tabeli 8. W latach 2010-2014 udział preferencji w PIT w podatkach dochodowych ulegał stopniowemu zmniejszeniu od 65,2\% do $59,5 \%$, a udział preferencji w CIT rósł od 34,8\% do 40,5\%, co było wynikiem wyższej dynamiki preferencji w CIT (wartość preferencji w CIT w 2014 r. była o 44,6\% wyższa niż w 2010 r., a w PIT o 13,2\%). Strukturę preferencji przedstawiono w tabeli 9 (wzięto pod uwagę te preferencje, których wartość w preferencjach z PIT przekraczała 5\%). W preferencjach z PIT (tak jak w ulgach od podatku w PIT) dominowała ulga na dzieci, która w badanym okresie stanowiła średnio $29,1 \%$ preferencji.

Tabela 8. Wielkość i struktura preferencji podatkowych w podatkach dochodowych w latach 2010-2014

\begin{tabular}{|l|c|c|c|c|c|}
\hline \multicolumn{1}{|c|}{ Wyszczególnienie } & 2010 & 2011 & 2012 & 2013 & 2014 \\
\hline $\begin{array}{l}\text { Preferencje podatkowe w podatkach } \\
\text { dochodowych (w mln zł): }\end{array}$ & 28438 & 29943 & 29710 & 32003 & 35298 \\
\hline - preferencje w PIT & 18552 & 19213 & 18904 & 19383 & 21002 \\
\hline - preferencje w CIT & 9886 & 10730 & 10806 & 12620 & 14296 \\
\hline $\begin{array}{l}\text { Preferencje podatkowe w podatkach } \\
\text { dochodowych (w \%): }\end{array}$ & 100,0 & 100,0 & 100,0 & 100,0 & 100,0 \\
\hline - preferencje w PIT & 65,2 & 64,2 & 63,6 & 60,6 & 59,5 \\
\hline- preferencje w CIT & 34,8 & 35,8 & 36,4 & 39,4 & 40,5 \\
\hline
\end{tabular}

Źródło: obliczenia własne na podstawie (Preferencje podatkowe... 2011-2015).

Preferencje z tytułu łącznego opodatkowania małżonków były natomiast równe średnio $15,7 \%$ preferencji, preferencje z tytułu dopłat do rolnictwa $11,2 \%$, prefe- 
rencje dotyczące świadczeń rodzinnych, dodatków rodzinnych i pielęgnacyjnych $8 \%$. Na wymienione powyżej cztery rodzaje preferencji przypadało średnio $64 \%$ wartości preferencji w PIT.

Tabela 9. Struktura preferencji w PIT w latach 2010-2014

\begin{tabular}{|l|c|c|c|c|c|}
\hline \multicolumn{1}{|c|}{ Wyszczególnienie } & 2010 & 2011 & 2012 & 2013 & 2014 \\
\hline Preferencje w PIT (w mln zł): & 18552 & 19213 & 18904 & 19383 & 21002 \\
\hline - ulga na dzieci & 5684 & 5740 & 5699 & 5530 & 5589 \\
\hline - łączne opodatkowanie dochodów małżonków & 2880 & 2979 & 3067 & 3174 & 3143 \\
\hline - dopłaty do rolnictwa & 2008 & 2334 & 1715 & 2445 & 2348 \\
\hline - świadczenia rodzinne, dodatki rodzinne & 1557 & 1625 & 1582 & 1540 & 1458 \\
\hline i pielęgnacyjne & & & & & \\
\hline - zwrot niewykorzystanej kwoty ulgi na dzieci & - & - & - & - & 1338 \\
\hline - pozostałe & 6423 & 6535 & 6841 & 6694 & 7126 \\
\hline Preferencje w PIT (w \%): & 100,0 & 100,0 & 100,0 & 100,0 & 100,0 \\
\hline - ulga na dzieci & 30,6 & 29,9 & 30,1 & 28,5 & 26,6 \\
\hline - łączne opodatkowanie dochodów małżonków & 15,5 & 15,5 & 16,2 & 16,4 & 15,0 \\
\hline - dopłaty do rolnictwa & 10,8 & 12,1 & 9,1 & 12,6 & 11,2 \\
\hline - świadczenia rodzinne, dodatki rodzinne & 8,4 & 8,5 & 8,4 & 7,9 & 6,9 \\
\hline i pielęgnacyjne & & & & & \\
\hline - zwrot niewykorzystanej kwoty ulgi na dzieci & - & - & - & - & 6,4 \\
\hline - pozostałe & 34,7 & 34,0 & 36,2 & 34,6 & 33,9 \\
\hline
\end{tabular}

Źródło: obliczenia własne na podstawie (Preferencje podatkowe... 2011-2015).

Tabela 10. Struktura preferencji w CIT w latach 2010-2014

\begin{tabular}{|l|c|c|c|c|c|}
\hline \multicolumn{1}{|c|}{ Wyszczególnienie } & 2010 & 2011 & 2012 & 2013 & 2014 \\
\hline Preferencje w CIT (w mln zł): & 9886 & 10730 & 10806 & 12620 & 14296 \\
\hline - straty z lat ubiegłych & 2143 & 2752 & 2576 & 3026 & 2966 \\
\hline - specjalne strefy ekonomiczne & 1448 & 1783 & 1596 & 2250 & 2512 \\
\hline - dochody organizacji non-profit & 924 & 845 & 938 & 1133 & 1059 \\
\hline - pozostałe & 5371 & 5350 & 5696 & 6211 & 7759 \\
\hline Preferencje w CIT (w \%): & 100,0 & 100,0 & 100,0 & 100,0 & 100,0 \\
\hline - straty z lat ubiegłych & 21,7 & 25,6 & 23,8 & 24,0 & 20,7 \\
\hline - specjalne strefy ekonomiczne & 14,7 & 16,6 & 14,8 & 17,8 & 17,6 \\
\hline - dochody organizacji non-profit & 9,3 & 7,9 & 8,7 & 9,0 & 7,4 \\
\hline - pozostałe & 54,4 & 49,9 & 52,7 & 49,2 & 54,3 \\
\hline
\end{tabular}

Źródło: obliczenia własne na podstawie (Preferencje podatkowe... 2011-2015). 
Strukturę preferencji w CIT ukazano w tabeli 10 (także w tym przypadku wzięto pod uwagę te preferencje, których wartość w preferencjach z CIT przekraczała 5\%). W całym rozpatrywanym okresie największe były preferencje dotyczące strat $\mathrm{z}$ lat ubiegłych (równe skutkowi budżetowemu ulg podatkowych od dochodu w CIT z tytułu strat z lat ubiegłych), które stanowiły średnio 23,2\% preferencji w CIT. Preferencje związane ze specjalnymi strefami ekonomicznymi były równe średnio 16,3\%, a preferencje dotyczące dochodów organizacji non-profit 8,5\% preferencji. Wartość trzech wymienionych rodzajów preferencji wynosiła średnio $48 \%$ preferencji w CIT.

\section{Ocena wielkości oraz finansowych skutków ulg i preferencji podatkowych w Polsce}

Dla dokonania oceny wielkości ulg oraz preferencji podatkowych w podatkach dochodowych odniesiono je do całej wielkości podatku należnego, a także do wielkości PKB (tabela 11). W latach 2010-2015 stosunek skutku budżetowego ulg podatkowych w PIT do PIT należnego ulegał stopniowemu obniżeniu od 15,7\% do $11,1 \%$ (średnio wynosił 13,1\%), a stosunek skutku budżetowego ulg podatkowych w CIT do CIT należnego rósł w pierwszych czterech latach, a później zmniejszał się i był równy średnio 9,8\%. Relacja preferencji w PIT do PIT należnego kształtowała się różnie, lecz była najwyższa w pierwszych dwóch latach badanego okresu i wynosiła średnio 39\%. Relacja preferencji w CIT do CIT należnego rosła poza rokiem 2011 i była równa średnio 39,7\%. Stosunek skutku budżetowego ulg podatkowych w PIT do PKB wynosił średnio 0,41\%, a stosunek skutku budżetowego ulg w CIT do PKB 0,18\%. Średnia wielkość relacji preferencji w PIT do PKB była równa $1,21 \%$, a relacji preferencji w CIT do PKB 0,72\% (tabela 11).

Wprawdzie analizowane podatki dochodowe nie zasilają w całości budżetu państwa (mają w nich udziały gminy, powiaty i województwa), ale ulgi podatkowe oraz preferencje podatkowe wykazywane były dla całości tych podatków. Z uwagi na to skutki finansowe opisywanych instrumentów powinny być przedstawione w stosunku do dochodów podatkowych budżetu państwa oraz jednostek samorządu terytorialnego, gdyż właśnie te dochody w wyniku stosowania opisywanych instrumentów zostają uszczuplone. Ze względu na dostępne informacje całość skutku finansowego ulg i preferencji podatkowych w podatkach dochodowych odniesiono do dochodów podatkowych budżetu państwa. Relacja skutku budżetowego ulg podatkowych w PIT, a także w CIT do dochodów podatkowych budżetu państwa w latach 2010-2015 wynosiła odpowiednio średnio 2,7\% oraz 1,1\%. Relacja skutku finansowego preferencji podatkowych (równa wartości preferencji 
Tabela 11. Charakterystyki ulg i preferencji podatkowych w PIT oraz CIT w latach 2010-2015 (w \%)

\begin{tabular}{|l|c|c|c|c|c|c|}
\hline \multicolumn{1}{|c|}{ Relacja } & 2010 & 2011 & 2012 & 2013 & 2014 & 2015 \\
\hline Skutek budżetowy ulg w PIT/PIT należny & 15,7 & 14,7 & 13,6 & 11,7 & 11,6 & 11,1 \\
\hline Skutek budżetowy ulg w CIT/CIT należny & 8,1 & 9,4 & 9,9 & 11,5 & 10,5 & 9,4 \\
\hline Preferencje w PIT/PIT należny & 42,4 & 40,8 & 37,5 & 36,4 & 37,8 & - \\
\hline Preferencje w CIT/CIT należny & 34,2 & 34,0 & 38,0 & 45,1 & 47,1 & - \\
\hline $\begin{array}{l}\text { Skutek budżetowy ulg w PIT/ dochody } \\
\text { podatkowe budżetu państwa }\end{array}$ & 3,1 & 2,9 & 2,8 & 2,6 & 2,5 & 2,5 \\
\hline $\begin{array}{l}\text { Skutek budżetowy ulg w CIT/dochody } \\
\text { podatkowe budżetu państwa }\end{array}$ & 1,1 & 1,2 & 1,1 & 1,3 & 1,2 & 1,1 \\
\hline $\begin{array}{l}\text { Preferencje w PIT/ dochody podatkowe } \\
\text { budżetu państwa }\end{array}$ & 8,3 & 7,9 & 7,6 & 8,0 & 8,2 & - \\
\hline $\begin{array}{l}\text { Preferencje w CIT/dochody podatkowe } \\
\text { budżetu państwa }\end{array}$ & 4,4 & 4,4 & 4,4 & 5,2 & 5,6 & - \\
\hline Skutek budżetowy ulg w PIT/PKB & 0,48 & 0,44 & 0,42 & 0,38 & 0,37 & 0,36 \\
\hline Skutek budżetowy ulg w CIT/PKB & 0,16 & 0,19 & 0,17 & 0,19 & 0,18 & 0,16 \\
\hline Preferencje w PIT/PKB & 1,28 & 1,23 & 1,16 & 1,17 & 1,22 & - \\
\hline Preferencje w CIT/PKB & 0,68 & 0,68 & 0,66 & 0,76 & 0,83 & - \\
\hline
\end{tabular}

Źródło: obliczenia własne na podstawie (Informacje dotyczqce rozliczenia podatku dochodowego od osób fizycznych... 2011-2016, Informacje dotyczqce rozliczenia podatku dochodowego od osób prawnych... 2011-2016, Rocznik Statystyczny Rzeczypospolitej Polskiej... 2011-2016).

Tabela 12. Deficyt sektora finansów publicznych a ulgi podatkowe i preferencje podatkowe

\begin{tabular}{|l|c|c|c|c|c|c|}
\hline \multicolumn{1}{|c|}{ Wyszczególnienie } & 2010 & 2011 & 2012 & 2013 & 2014 & 2015 \\
\hline $\begin{array}{l}\text { Deficyt sektora finansów publicznych } \\
\text { (w mln zł) }\end{array}$ & 85106 & 56337 & 37560 & 48354 & 39615 & 43990 \\
\hline (1) Skutek budżetowy ulg w PIT (w mln zł) & 6876 & 6933 & 6870 & 6231 & 6423 & 6527 \\
\hline (2) Skutek budżetowy ulg w CIT (w mln zł) & 2341 & 2953 & 2806 & 3226 & 3179 & 2937 \\
\hline (3) Razem 1 + 2 (w mln zł) & 9217 & 9886 & 9676 & 9457 & 9602 & 9464 \\
\hline (4) Preferencje podatkowe w PIT (w mln zł) & 18552 & 19213 & 18904 & 19383 & 21002 & - \\
\hline (5) Preferencje podatkowe w CIT (w mln zł) & 9886 & 10730 & 10806 & 12620 & 14296 & - \\
\hline (6) Razem 4 + 5 (w mln zł) & 28438 & 29943 & 29710 & 32003 & 35289 & - \\
\hline $\begin{array}{l}\text { Relacja 1 + 2/ deficyt sektora finansów } \\
\text { publicznych (w \%) }\end{array}$ & 10,8 & 17,5 & 25,8 & 19,6 & 24,2 & 21,5 \\
\hline $\begin{array}{l}\text { Relacja 4 + 5/deficyt sektora finansów } \\
\text { publicznych (w \%) }\end{array}$ & 33,4 & 53,1 & 79,1 & 66,2 & 89,1 & - \\
\hline
\end{tabular}

Źródło: obliczenia własne na podstawie (Informacje dotyczqce rozliczenia podatku dochodowego od osób fizycznych... 2011-2016, Informacje dotyczqce rozliczenia podatku dochodowego od osób prawnych... 2011-2016, Rocznik Statystyczny Rzeczypospolitej Polskiej... 2011-2016). 
podatkowych) w PIT oraz w CIT do dochodów podatkowych budżetu państwa stanowiła odpowiednio średnio $8 \%$ oraz $4,6 \%$ (tabela 11).

W badanych latach skutek budżetowy ulg podatkowych w PIT i CIT łącznie był zawsze mniejszy od wartości preferencji podatkowych w samym CIT i ok. dwukrotnie mniejszy niż wartość preferencji w PIT (tabela 12). Skoro (jak już wspomniano) stosowanie ulg i preferencji podatkowych powoduje redukcję dochodów podatkowych, to w warunkach istnienia deficytu sektora finansów publicznych przydatne jest zestawienie skutku budżetowego ulg oraz preferencji podatkowych z wielkością deficytu sektora finansów publicznych. Relacja skutku budżetowego ulg podatkowych w PIT i w CIT łącznie do wielkości deficytu sektora finansów publicznych kształtowała się różnie i wynosiła od 10,8\% do 25,8\%. Relacja preferencji podatkowych w PIT i w CIT łącznie do deficytu sektora finansów publicznych w latach 2010-2014 wahała się natomiast od 33,4\% do 89,1\%. Widoczna jest duża zmienność ukazanych relacji spowodowana głównie tym, że deficyt sektora finansów publicznych (rozumiany jako wartość bezwzględna ujemnego salda finansów publicznych) kształtował się różnie i charakteryzował większą zmiennością niż ulgi i preferencje podatkowe. Przedstawione relacje były wprawdzie najwyższe w 2012 r. i 2014 r., ale w tych latach deficyt sektora finansów publicznych był najniższy (nierównowaga była najmniejsza).

\section{Podsumowanie}

Zarówno ulgi podatkowe, jak i preferencje podatkowe w podatkach dochodowych sprzyjają realizacji pozafiskalnych funkcji podatków. Ich istnienie może ułatwić trudną sytuację wielu osób i firm, a także skłaniać podatników do działań, które w przyszłości okażą się korzystne dla gospodarki oraz społeczeństwa jako całości. Jednocześnie rezultatem wykorzystania ulg i preferencji podatkowych jest zmniejszenie dochodów podatkowych, co nie jest obojętne w sytuacji, gdy przez wiele kolejnych lat budżet zamyka się deficytem. Stosowanie tych instrumentów powinno być zatem przemyślane, a osiągnięte dzięki nim rezultaty analizowane w dłuższym przedziale czasu.

Z przeprowadzonych analiz wynika, że w badanym okresie w podatku dochodowym od osób fizycznych ulgi od podatku (wśród których dominowała ulga na dzieci) zawsze przewyższały ulgi podatkowe od dochodu. W stosunku do 2010 r. wielkość ulg od dochodu i podatku łącznie była w 2014 r. niższa o 18,3\%, a w 2015 r. niższa o 16,5\%, co było spowodowane zmniejszeniem ulg podatkowych od dochodu (głównie ulgi z tytułu użytkowania sieci Internet). Skutek budżetowy ulg podatkowych łącznie był w 2014 r. niższy o 6,6\% niż w 2010 r., 
a w 2015 r. niższy o 5,1\%. Preferencje podatkowe w PIT (w strukturze których największe znaczenie miały ulga na dzieci oraz ulga z tytułu łącznego opodatkowania dochodów małżonków) wykazywały natomiast w badanym okresie tendencję rosnącą i były w 2014 r. wyższe o 13,2\% niż w 2010 r.

Relacja skutku budżetowego ulg podatkowych w PIT do PIT należnego wynosiła średnio $13,1 \%$, a relacja preferencji w PIT do PIT należnego 39\%, a zatem była blisko 3 razy większa.

W podatku dochodowym od osób prawnych ulgi podatkowe od dochodu i podstawy opodatkowania (wśród nich największa była ulga $\mathrm{z}$ tytułu strat $\mathrm{z}$ lat ubiegłych) zdecydowanie dominowały nad ulgami od podatku, gdyż stanowiły średnio 99,5\% ulg razem. Wielkość ulg razem w stosunku do 2010 r. była w 2014 r. o 39\% większa, a w 2015 r. większa o 24,1\%, natomiast skutek budżetowy ulg razem był wyższy odpowiednio o $35,8 \%$ oraz o $25,5 \%$. Preferencje podatkowe w CIT (w strukturze których największe znaczenie miały preferencje z tytułu strat $\mathrm{z}$ lat ubiegłych oraz specjalnych stref ekonomicznych) w badanym okresie wykazywały tendencję rosnącą i w 2014 r. były wyższe o 44,6\% niż w 2010 r. Relacja skutku budżetowego ulg podatkowych w CIT do CIT należnego była równa średnio 9,8\%, a relacja preferencji w CIT do CIT należnego średnio wynosiła 39,7\%, czyli była ok. 4 razy większa. Wprawdzie ilościowo skutek budżetowy ulg podatkowych w PIT przewyższał skutek budżetowy ulg podatkowych w CIT, ale skutek budżetowy ulg podatkowych w CIT wzrósł bardziej. Podobnie było w przypadku preferencji podatkowych. Były one wyższe w PIT niż w CIT, lecz preferencje podatkowe w CIT wzrosły bardziej. W latach 2010-2015 relacja skutku budżetowego ulg w PIT (CIT) do dochodów podatkowych budżetu państwa wahała się w granicach od $2,5 \%$ do $3,1 \%$ (od 1,1\% do 1,3\%), relacja preferencji podatkowych w PIT (CIT) do dochodów podatkowych budżetu państwa mieściła się w przedziale od 7,6\% do 8,3\% (od 4,4\% do 5,6\%).

Przeprowadzona analiza pozwoliła ustalić rząd wielkości ulg i preferencji podatkowych, a także ukazała ich skutki finansowe, co stanowi podstawę do rozwinięcia badań w tym zakresie. Istnieje potrzeba spójnej analizy omówionych instrumentów i podjęcia decyzji w sprawie ewentualnej ich korekty. Z jednej strony chodzi o wspomaganie właściwego pełnienia przez podatki funkcji pozafiskalnych (bez zbytniego nasilania złożoności systemu podatkowego), a z drugiej o zwiększenie przejrzystości gospodarowania środkami publicznymi, przy czym obie te sprawy w praktyce nie są łatwe do pogodzenia.

\section{Literatura}

Dziemianowicz R.I., Wyszkowski A., Budlewska R. (2014), Tax expenditures jako ukryta forma wydatków publicznych, „Gospodarka Narodowa”, nr 3. 
Gaudemet P.M. (1989), Finanse publiczne, PWE, Warszawa.

Informacje dotyczqce rozliczenia podatku dochodowego od osób fizycznych, raporty za lata 2010-2015 (2011-2016), Ministerstwo Finansów, Warszawa.

Informacje dotyczq̨e rozliczenia podatku dochodowego od osób prawnych, raporty za lata 2010-2015 (2011-2016), Ministerstwo Finansów, Warszawa.

Owsiak S. (2017), Finanse publiczne. Współczesne ujęcie, Wydawnictwo Naukowe PWN, Warszawa.

Preferencje podatkowe w Polsce, raporty za lata 2010-2014 (2011-2015), Ministerstwo Finansów, Warszawa.

Rocznik Statystyczny Rzeczypospolitej Polskiej, 2010-2015 (2011-2016), GUS, Warszawa. Stiglitz J.E. (2004), Ekonomia sektora publicznego, Wydawnictwo Naukowe PWN, Warszawa.

Ustawa z dnia 29 sierpnia 1997 r. Ordynacja podatkowa, Dz.U. nr 1137, poz. 926.

Wolański R. (2009), System podatkowy w Polsce, Oficyna a Wolters Kluwer business, Warszawa.

\section{Tax Relief and Tax Preferences in Income Tax in Poland}

(Abstract)

The article presents tax relief and tax preferences in income taxes (PIT and CIT) in Poland in the years 2010-2015. Tax relief is understood as the possibility of reducing the earned income or calculated tax by certain amounts (mainly under the Act on tax). Income relief reduced the amount of the tax base, and thus indirectly affected the amount of tax. On the other hand, tax relief led to a tax reduction by the amount of the relief. In turn, tax preferences were interpreted as derogations from the country's tax standard.

Both tax relief and tax preferences are an important instrument of fiscal policy that is conducive to implementing tax regulatory and stimulating functions. However, they cause a decrease in budget tax revenues, if to varying degrees. The article characterises the size, structure and tendency of the development of tax relief and preferences, as well as the extent to which they have contributed to the reduction of budget revenue from personal income tax and corporate income tax.

Keywords: tax reliefs, tax preferences, budget revenues, income taxes. 